\title{
PENGARUH PENGGUNAAN MEDIA FLASH CARD TERHADAP KETERAMPILAN MENULIS KARANGAN NARASI SISWA KELAS III SDN 188 PEKANBARU
}

\author{
Lydia Emilsa, Guslinda \\ Lydiaemilsa8@gmail.com, guslinda@lecturer.unri.ac.id \\ Program Studi Pendidikan Guru Sekolah Dasar \\ Universitas Riau, Indonesia
}

\section{ARTICLE INFO}

Submitted:

$4^{\text {th }}$ July 2019

Accepted:

17 September 2019

$17^{\text {th }}$ September 2019

Published:

7 Oktober 2019

$7^{\text {th }}$ October 2019
4 Juli 2019

\section{ABSTRACT}

\begin{abstract}
The background of this research is the low level of narrative essay writing skills. This is due to several factors including because students are less interested and feel bored with writing material, students have difficulty in choosing words and use of spelling, it is because students do not have a broad vocabulary, so the words used are just that, so essays written only modest, usually consisting of 1-2 sentences. Then students are less skilled in connecting one sentence with another sentence so that no good paragraphs are formed. Students are confused in placing punctuation marks such as periods, commas, question marks, and exclamation points that are still incorrect. This study aims to determine the effect of the use of flash card media on the narrative essay writing skills of third grade students at SDN 188 Pekanbaru. This research method uses quasi experimental Nonequivalent Control Group Design. The population of this research is class III students of SDN 188 Pekanbaru, which is class IIIA, amounting to 40 students as the control class and class IIIB, which amounts to 40 students as the experimental class. The sampling technique uses saturated samples. The instrument used as data in this study was an essay test in the form of a narrative essay writing assignment. Hypothesis testing is done by using the " $t$ " test and Effect Size (ES). Based on the results of the study shows that the use of flash card media affects the writing skills of students' narrative essays and the magnitude of the effect offlash card media is included in the medium category.
\end{abstract}

Keywords: flash card media, writing ability, narrative text

Abstrak: Latar belakang penelitian ini adalah rendahnya keterampilan menulis karangan narasi kelas rendah. Hal ini disebabkan beberapa faktor diantaranya dikarenakan siswa kurang tertarik dan merasa bosan dengan materi menulis, siswa kesulitan dalam pemilihan kata dan penggunaan ejaan, hal itu karena siswa tidak memiliki pembendaharaan kata yang luas, sehingga kata-kata yang digunakan itu-itu saja, sehingga karangan yang ditulis hanya seadanya, biasanya terdiri dari 1-2 kalimat. Kemudian siswa kurang terampil dalam menghubungkan antara kalimat satu dengan kalimat lainnya sehingga tidak terbentuk paragraf yang baik. Siswa banyak bingung dalam menempatkan tanda baca seperti tanda titik, tanda koma, tanda tanya, dan tanda seru masih kurang tepat. Penelitian ini bertujuan untuk mengetahui pengaruh penggunaan media flash card terhadap keterampilan menulis karangan narasi siswa kelas III SDN 188 Pekanbaru. Metode penelitian ini menggunakan kuasi eksperimen Nonequivalent Control Group Design. Populasi dari penelitian ini adalah siswa kelas III SDN 188 Pekanbaru yaitu kelas IIIA yang berjumlah 40 siswa sebagai kelas kontrol dan kelas IIIB yang berjumlah 40 siswa sebagai kelas eksperimen. Teknik pengambilan sampel dengan menggunakan sampel jenuh. Instrumen yang digunakan sebagai data dalam penelitian ini adalah tes essay dalam bentuk penugasan menulis karangan narasi. Pengujian hipotesis dilakukan dengan menggunakan uji "t" dan Effect Size (ES). Berdasarkan hasil penelitian menunjukkan bahwa penggunaan media flash card berpengaruh terhadap keterampilan menulis karangan narasi siswa dan besarnya pengaruh media flash card termasuk dalam kategori sedang.

Kata Kunci: media flash card, keterampilan menulis, karangan narasi

CITATION

Emilsa, L., \& Guslinda. (2019). Pengaruh Penggunaan Media Flash Card terhadap Keterampilan Menulis Karangan Narasi Siswa Kelas III SDN 188 Pekanbaru. Primary: Jurnal Pendidikan Guru Sekolah Dasar, 8 (2), 101-114. DOI: http://dx.doi.org/10.33578/jpfkip.v8i2.7566. 


\section{PRIMARY : JURNAL PENDIDIKAN GURU SEKOLAH DASAR \\ Volume 8 Nomor 2 Oktober 2019 \\ DOI : http://dx.doi.org/10.33578/jpfkip.v8i1.7556 \\ ISSN : 2303-1514 | E-ISSN : 2598-5949 \\ https://primary.ejournal.unri.ac.id/index.php/JPFKIP}

\section{PENDAHULUAN}

Bahasa merupakan alat komunikasi untuk membantu setiap orang agar dapat terkoneksi antara satu sama lain. Oleh sebab itu, bahasa menjadi bagian yang sangat penting untuk dipelajari dan dikuasai oleh setiap orang baik melalui jenjang formal maupun non formal. Ada empat keterampilan yang harus dikuasai dalam berbahasa. Keempat keterampilan itu saling berkaitan. Salah satunya adalah keterampilan menulis. Menulis merupakan keterampilan yang sangat penting baik di sekolah maupun di masyarakat. Hal itu disebabkan karena menulis dijadikan sebagai sarana komunikasi tertulis di era globalisasi.

Berdasarkan hasil pengamatan dan pengalaman dalam pembelajaran menulis karangan narasi yang dilaksanakan di SDN 188 Pekanbaru, keterampilan menulis karangan narasi masih rendah dapat dilihat dari nilai rata-rata yang di dapat siswa. Hal ini disebabkan beberapa faktor diantaranya dikarenakan siswa kurang tertarik dan merasa bosan dengan materi menulis, siswa kesulitan dalam pemilihan kata dan penggunaan ejaan, hal itu karena siswa tidak memiliki pembendaharaan kata yang luas, sehingga katakata yang digunakan itu-itu saja, sehingga karangan yang ditulis hanya seadanya, biasanya terdiri dari 1-2 kalimat. Kemudian siswa kurang terampil dalam menghubungkan antara kalimat satu dengan kalimat lainnya sehingga tidak terbentuk paragraf yang baik. Siswa banyak bingung dalam menempatkan tanda baca seperti tanda titik, tanda koma, tanda tanya , dan tanda seru masih kurang tepat.

Salah satu upaya yang dapat dilakukan untuk mengatasi permasalahan tersebut adalah dengan memilih dan mengunakan media pembelajaran yang tepat, diantaranya yaitu dengan menggunakan media flash card. Penggunaan media flash card dipandang lebih cocok mengingat berbagai karakteristik yang ada pada media. Karena media flash card merupakan salah satu wahana penyalur atau wadah pembelajaran yang berbentuk kartu bergambar dan disertai kata-kata kunci. Selain itu juga dapat meningkatkan kemampuan berfikir dan membantu siswa dalam menuangkan ide/gagasannya ke dalam tulisan, sehingga gagasan tersebut dapat disusun menjadi tulisan narasi.

Berdasarkan latar belakang di atas, penulis mengangkat permasalahan tersebut dalam penelitian yang berjudul "Pengaruh Penggunaan Media flash card terhadap Keterampilan Menulis Karangan Narasi Siswa Kelas III SDN 188 Pekanbaru".

Menurut Soeparno (dalam Khasanah, 2011) mengatakan bahwa media adalah suatu alat yang dipakai sebagai saluran (chanel) untuk menyampaikan pesan (message) atau informasi dari suatu sumber (resource) kepada penerimanya (receiver). Kata media berasal dari bahasa latin, yang bentuk tunggalnya adalah medium yang artinya perantara atau pengantar.

Menurut Arsyad (2009) berpendapat bahwa media adalah segala alat fisik yang menyajikan peran serta merangsang siswa untuk belajar contohnya buku, film, kaset, dan lain-lain. Dasar pertimbangan dalam pemilihan media pembelajaran sangat sederhana, yaitu dapat memenuhi kebutuhan atau mencapai tujuan yang diinginkan atau tidak.

Media pembelajaran merupakan salah satu faktor penentu keberhasilan pembelajaran. Melalui media proses pembelajaran bisa lebih menarik dan menyenangkan (joyful learning). Aspek penting penggunaan media adalah membantu memperjelas pesan pembelajaran.

Berdasarkan pendapat para ahli diatas dapat disimpulkan bahwa media pembelajaran adalah segala sesuatu yang dapat meyampaikan atau menyalurkan pesan dari suatu sumber secara terencana, sehingga terjadi lingkungan belajar yang kondusif dimana penerimanya dapat melakukan proses belajar secara efisien dan efektif yang digunakan dalam menyampaikan informasi untuk mempermudah komunikasi dan interaksi anatara guru dan siswa dalam menunjang proses pengajaran.

Menurut Sadiman (dalam Amaliyah, 2018) mengatakan bahwa "Diantara beberapa media pendidikan, gambar adalah media paling umum yang dipakai yang merupakan bahasa yang umum dipakai dan dapat dimengerti dan dinikmati dimana-mana sehingga pepatah cina mengatakan bahwa sebuah gambar berbicara lebih banyak daripada seribu". 
Beberapa manfaat penggunaan media dalam pembelajaran menurut Arsyad (2009) manfaat media pembelajaran sebagai berikut: 1) Pengajaran akan lebih menarik perhatian siswa, sehingga dapat menumbuhkan motivasi belajar; 2) Bahan pengajaran akan lebih jelas maknanya, sehingga dapat lebih dipahami oleh siswa dan memungkinkannya menguasai dan mencapai tujuan pengajaran; 3) Metode mengajar akan lebih bervariasi, tidak semata-mata komunikasi verbal melalui penuturan kata-kata guru, sehingga siswa tidak bosan dan guru tidak kehabisan tenaga, apalagi kalau guru mengajar setiap jam pelajaran; 4) Siswa dapat lebih banyak melakukan kegiatan, sebab tidak hanya mendengarkan uraian guru, tetapi aktivitas lain seperti: mengamati, melakukan, mendemonstrasikan, memerankan, dll.

Asumsi bahwa karakteristik siswa sekolah dasar dalam kegiatan belajar teknologi adalah bahwa mereka sebagian besar menggunakan indera penglihatan mereka. Ini memperkuat alasan bagi guru untuk menggunakan media visual. Ada banyak jenis media visual mulai dari yang paling sederhana sampai yang paling rumit apakah mereka diilustrasikan atau tidak. Flash card atau kartu bergambar bergambar adalah salah satu media visual bergambar sederhana untuk memfasilitasi metode pembelajaran siswa. Mudah dipahami dan dipahami oleh mereka dan mudah dibuat serta murah, (Lisa, 2019).

Pendapat Dini Indriani dalam Aningsih, 2017) mengungkapkan bahwa "flash card adalah media pembelajaran dalam bentuk kartu bergambar yang ukurannya seukuran kartu pos atas sekitar 25 cm x 30 cm". Flash card biasanya berisi kata-kata, gambar atau kombinasinya dan dapat digunakan untuk mengembangkan perbendaharaan kata dalam pelajaran bahasa pada umumnya dan pada bahasa asing pada khususnya (Susilana dalam Made, 2015).

Menurut Wright (1976) menyatakan bahwa kartu flash card adalah kartu yang dicetak dengan kata-kata dan/ gambar yang dapat ditangani dengan mudah oleh guru. Setiap kartu berisi gambar yang dapat dibuat sendiri oleh guru atau diambilnya dari majalah, koran, atau buku. Dibagian bawah ada item kosa kata. Menurut Baleghizadeh dan Anshoori (dalam Eka dkk, 2017) flash card merupakan sebuah kartu yang mana terdapat sebuah kata, kalimat atau gambar di dalamnya. Flash card merupakan media yang sangat praktis karena dapat dibuat secara bersamasama oleh guru dan siswa.

Dari beberapa pengertian di atas dapat disimpulkan bahwa media flash card merupakan salah satu media pembelajaran yang berbentuk grafis berupa kartu kecil bergambar, biasanya terbuat dengan menggunakan foto, simbol, atau gambar yang ditempelkan pada sisi depan dan sisi belakang terdapat keterangan berupa fakta atau kalimat dari gambar flash card tersebut.

Langkah-langkah penggunaan media pembelajaran flash card diuraikan oleh Indriana (dalam Angraeny, 2017) yaitu : 1) Guru membagi media flash card yang terdapat gambar kepada siswa, 2) Guru membimbing siswa mengurutkan gambar, 3) Guru bertanya jawab tentang isi gambar dengan siswa, 4) Pada akhir pembelajaran siswa diberi tugas untuk membuat karangan dari gambar atau flash card yang ada, 5) Jika sajian menggunakan cara permainan: a) Letakkan kartukartu secara acak pada sebuah kotak yang berada jauh dari siswa, b) Siapkan siswa yang akan berlomba, c) Guru memerintahkan siswa untuk mencari kartu yang berisi gambar, teks, atau lambang sesuai".

Beberapa kelebihan dan kelemahan media flash card dalam menulis karangan narasi menurut Susilana dan Riyana (dalam Khoriyah, 2012). Kelebihannya yaitu:

\section{1) Mudah Dibawa-Bawa}

Dengan ukuran yang kecil flash card dapat disimpan di dalam tas bahkan di saku, dapat digunakan dimana saja, di kelas ataupun di luar kelas.

\section{2) Praktis}

Dalam menggunakan media ini guru tidak perlu memiliki keahlian khusus, media ini tidak perlu juga membutuhkan listrik. Jika akan menggunakan kita tinggal menyusun urutan gambar sesuai dengan keinginan kita, jika sudah digunakan tinggal disimpan kembali dengan cara diikat atau menggunakan kotak khusus supaya tidak tercecer.

\section{3) Gampang Diingat}

Karakteristik media flash card adalah menyajikan pesan-pesan pendek pada setiap kartu yang disajikan. Sajian pesan-pesan pendek ini akan 
memudahkan siswa untuk mengingat pesan tersebut.

\section{4) Menyenangkan}

Media flash card dalam Penggunaannya bisa melalui permainan. Misalnya siswa secara berlomba untuk mencari sesuai perintah. Selain mengasah kemampuan kognitif juga melatih ketangkasan (fisik).

Kekurangan media flash card yaitu:

1) Gambar hanya menekankan persepsi indra mata.

2) Gambar benda yang terlalu kompleks kurang efektif untuk kegiatan pembelajaran.

3) Ukurannya sangat terbatas untuk kelompok besar.

Aktivitas menulis melibatkan beberapa unsur, yaitu: penulis sebagai penyampaian pesan, isi tulisan, saluran atau media, dan pembaca. Merupakan satu diantara keterampilan bahasa yang wajib dukuasai siswa SD (Peraturan Menteri No.22 Tahun 2006 tentang Standar Isi, 2006). Pendapat dari Dalman (2011) menulis merupakan sesuatu kegiatan komunikasi berupa penyampaian pesan (informasi) secara tertulis kepada pihak lain dengan menggunakan bahasa tulis sebagai alat atau medianya.

Berdasarkan dari beberapa pendapat ahli di atas, dapat disimpulkan bahwa menulis adalah proses penyampian pikiran, angan-angan, perasaan dalam bentuk lambang/ tanda/ tulisan/ yang bermakna.

Ciri-ciri tulisan yang baik yaitu antara lain: 1) tulisan yang baik mencerminkan kemampuan penulis mempergunakan nada yang serasi; 2) mencerminkan kemampuan penulis menyusun bahan-bahan yang tersedia menjadi suatu keseluruhan yang utuh; 3) mencerminkan kemampuan penulis untuk menulis dengan jelas dan tidak samar-samar. Memanfaatkan struktur kalimat, bahasa, dan contoh-contoh sehingga maknanya sesuai dengan yang diinginkan oleh penulis; 4) mencerminkan kemampuan penulis untuk menulis secara meyakinkan; 5) mencerminkan kemampuan penulis untuk mengkritik naskah tulisannya yang pertama dan memperbaikinya; dan 6) mencerminkan kebanggaan penulis dalam naskah atau manuskrip. Syarat-syarat menulis yaitu: 1) kita harus kaya akan ide, ilmu pengetahuan, dan pengalaman hidup; 2) disamping memiliki pengetahuan yang mendalam dan luas, serta pengalaman hidup yang kaya, kita harus memiliki intuisi yang tajam dan jiwa yang arif; dan 3) kita harus memiliki kakayaan berbahasa.

Tujuan menulis menurut Tarigan (dalam Amaliyah, 2018) yaitu antara lain sebagai berikut: 1) menyampaikan pokok fikiran atau gagasan pada pembaca; 2) menyampaikan informasi tentang suatu cerita kepada pembaca; 3) memberikan hiburan pada pembaca; dan 4) mempengaruhi atau mengajak pembaca malalui tulisannya.

Ada beberapa yang harus diperhatikan dalam menulis karangan (Putri, 2017) yaitu: 1) penggunaan ejaan yang baik dan benar; 2) menggunakan tanda baca.

Menurut purwanto (dalam Yulianti, 2017) karangan merupakan karya tulis dari kegiatan seseorang untuk mengungkapkan gagasan dan menyampaikannya melalui bahasa tulis kepada pembaca untuk dipahami.

Narasi adalah tulisan yang berupa rangkaian peristiwa yang terjadi dalam satu kesatuan waktu. Narasi disebut juga cerita. Cerita merupakan tulisan yang mempunyai karakter, setting, waktu, dan masalah. Namun, narasi juga dapat ditulis berdasarkan pengalaman pribadi, pengamatan, atau wawancara. Sebagai suatu tulisan, narasi dikembangkan dengan memperhatikan prinsip-prinsip dasar sebagai tumpuan berpikir yaitu alur (plot), penokohan, latar titik pandang, pemilihan detail peristiwa.

Langkah-langkah mengembangkan karangan narasi adalah sebagai berikut: 1) tentukan dulu tema dan amanat yang akan disampaikan; 2) tetapkan sasaran pembaca kita; 3) rancang peristiwa-peristiwa utama yang akan ditampilkan dalam bentuk skema alur; 4) bagi peristiwa utama itu kedalam bagian awal, perkembangan, dan akhir cerita; 5) rincian peristiwa-peristiwa utama ke dalam detail-detail peristiwa sebagai pendukung cerita; dan 6) susun tokoh dan perwatakan, latar, dan sudut pandang. 


\section{PRIMARY : JURNAL PENDIDIKAN GURU SEKOLAH DASAR \\ Volume 8 Nomor 2 Oktober 2019 \\ DOI : http://dx.doi.org/10.33578/jpfkip.v8i1.7556 \\ ISSN : 2303-1514 | E-ISSN : 2598-5949 \\ https://primary.ejournal.unri.ac.id/index.php/JPFKIP}

\section{METODE PENELITIAN}

Penelitian ini dilakukan di kelas III SDN 188 Pekanbaru yang beralamat di Jalan Anggrek 2 Garuda Sakti Km. 2 Kelurahan Air Putih, Kecamatan Tampan, Kota Pekanbaru, provinsi Riau. Penelitian ini dilakukan pada semester genap tahun ajaran 2018/2019. Waktu pelaksanaannya dilakukan pada tanggal 02 Februari 2019 sampai dengan 09 Maret 2019.

Jenis penelitian ini adalah penelitian kuantitatif dengan metode eksperimen dengan menggunakan desain penelitian Non equivalent control group design. Teknik pengambilan sampel dalam penelitian yang digunakan adalah sampel jenuh. Dalam rancangan Non equivalent control group design ini digunakan dua kelas sebagai subjek penelitian, yaitu kelas eksperimen dan kelas kontrol. Kelas eksperimen adalah kelas yang mendapat perlakuan berupa penggunaan media flash card sedangkan kelas kontrol adalah kelas yang tidak mendapat perlakuan. Populasi penelitian ini adalah seluruh siswa kelas III SDN 188 Pekanbaru sebanyak 80 orang yang terdiri dari 2 kelas yaitu kelas III A dan kelas III B. Sampel dalam penelitian ini adalah seluruh anggota populasi yaitu siswa kelas IIIA dan IIIB. Untuk menentukan kelas eksperimen dan kontrol berdasarkan nilai hasil menulis karangan narasi siswa. Kelas yang dapat nilai rendah itulah yang menjadi kelas ekperimen dan kelas yang mendapat nilai tinggi jadi kelas kontrol.

Teknik pengumpulan data yang digunakan peneliti adalah tes. Siswa diminta membuat karangan narasi berdasarkan flash card. Tes yang diberikan sebanyak dua kali, pertama pretest dengan tujuan untuk mengetahui kemampuan awal siswa dan kedua posttest untuk mengetahui hasil akhir setelah diberikan perlakuan di kelas eksperimen dan kontrol. Indikator yang digunakan untuk menilai keterampilan menulis karangan narasi pada siswa yaitu tema, diksi, alur, ejaan dan tanda baca.

Dalam penyusunan instrumen penilaian karangan narasi ini, peneliti menggunakan skala likert. Untuk skor nilai setiap indikator (4) Apabila semua indikator terlihat, (3) Apabila ada tiga indikator yang terlihat, (2) Apabila ada dua indikator yang terlihat, (1) Apabila hanya satu indikator yang terlihar.

Pada pengujian validitas media flash card dan rubrik penilaian dalam menulis karangan narasi di SDN 188 Pekanbaru dilakukan melalui proses review oleh salah satu dosen yang berasal dari Prodi PGSD FKIP UNRI, Elvina, M.Pd. Apabila telah divalidkan, maka sudah dapat digunakan dalam penelitian.

Teknik analisis data yang digunakan dalam penelitian ini menggunakan rumus statistik. Sebelum dilakukan pengolahan data, terlebih dahulu dilakukan pemberian skor terhadap hasil tes berupa pretest dan posttest baik di kelas eksperimen maupun pada kelas kontrol. Dalam memberikan skor dari karangan narasi siswa berdasarkan rubrik penilain berdasarkan rumus:

$\mathrm{S}=\frac{N}{R} 100$

( Purwanto, 2010)

Keterangan:

$\mathrm{S}=$ Nilai yang diharapkan

$\mathrm{R}=$ Jumlah skor dari indikator

$\mathrm{N}=$ Skor maksimum

Untuk interval dan kategori keterampilan menulis karangan narasi siswa dapat dilihat pada tabel berikut ini:

Tabel 1. Interval Penilaian Keterampilan Menulis Karanga Narasi Siswa

\begin{tabular}{c|c}
\hline Interval & Kategori \\
\hline $86-100$ & sangat terampil \\
$76-85$ & Terampil \\
$56-75$ & Cukup Terampil \\
$10-55$ & Kurang Terampil \\
\hline
\end{tabular}

(Nurgiyantoro, 2014) 


\section{PRIMARY : JURNAL PENDIDIKAN GURU SEKOLAH DASAR \\ Volume 8 Nomor 2 Oktober 2019 \\ DOI : http://dx.doi.org/10.33578/jpfkip.v8i1.7556 \\ ISSN : 2303-1514 | E-ISSN : 2598-5949 \\ https://primary.ejournal.unri.ac.id/index.php/JPFKIP}

Kemudian dilanjutkan dengan

menghitung rata-rata skor, uji normalitas, uji
Homogenitas, menghitung standar devisiasi, uji ttest, kemudian dilanjutkan dengan Effect Size

\section{HASIL DAN PEMBAHASAN}

Hasil penelitian yang diperoleh terdiri dari skor kemampuan menulis karangan narasi siswa. Kemampuan menulis karangan narasi berupa tes awal (pretest) dan tes akhir (posttest) antara kelas eksperimen dan kelas kontrol.

\section{Analisis Hasil Tes Awal (Pretest)}

Tes Awal (pretest) adalah tes kemampuan menulis karangan narasi siswa sebelum diberikan perlakuan berupa penggunaan media flash card di kelas eksperimen dan pembelajaran konvensional di kelas kontrol. Hasil tes awal kedua kelas dapat penelitian dapat dilihat pada tabel 2 berikut:

Tabel 2. Data Tes Awal Kelas Eksperimen dan Kelas Kontrol

\begin{tabular}{lcccccc}
\hline \multicolumn{1}{c}{ Kelas } & $\begin{array}{c}\text { Jumlah } \\
\text { siswa } \\
(\mathbf{n})\end{array}$ & $\begin{array}{c}\text { Rata- } \\
\text { Rata } \\
(\overline{\mathbf{x}})\end{array}$ & $\begin{array}{c}\text { Standar } \\
\text { Devisiasi } \\
(\mathbf{s})\end{array}$ & $\begin{array}{c}\text { Varians } \\
\left(\mathbf{s}^{2}\right)\end{array}$ & $\begin{array}{c}\text { Nilai } \\
\text { Minimal }\end{array}$ & $\begin{array}{c}\text { Nilai } \\
\text { Maksimal }\end{array}$ \\
\hline Eksperimen & 40 & 55,94 & 15,436 & 238,281 & 31,25 & 81,25 \\
Kontrol & 40 & 56,25 & 13,049 & 170,27 & 31,25 & 81,25 \\
\hline
\end{tabular}

Berdasarkan tabel 2 dapat dilihat bahwa terdapat perbedaan rata-rata skor tes awal (pretest) antara kelas eksperimen dengan kelas kontrol. Namun, untuk dapat mengetahui ada atau tidaknya perbedaan yang signifikan maka dilakukan uji t, sebelum itu maka dilakukan uji normalitas dan uji homogenitas terhadap skor tes awal (pretest) kelas eksperimen maupun kelas kontrol. Untuk analisis data dijelaskan sebagai berikut:

\section{a) Uji Normalitas Skor Tes Awal Kelas} Eksperimen dan Kelas Kontrol

Uji normalitas data ini menggunakan uji liliefors karena data merupakan data tunggal. Uji normalitas dilakukan untuk mengetahui normalitas data skor tes awal antara kelas eksperimen dan kelas kontrol, dengan perumusan hipotesis sebagai berikut:

Ho: Skor tes awal berdistribusi normal

Ha: Skor tes awal berdistribusi tidak normal

Pengujian hipotesis menggunakan taraf signifikan $\alpha=0,05$ dan $\mathrm{L}_{\text {tabel }}=0,140$ dengan kriteria sebagai berikut:

Jika $\mathrm{L}_{\text {maks }} \leq \mathrm{L}_{\text {tabel }}$, maka Ho diterima berarti data berdistribusi normal

Jika $\mathrm{L}_{\text {maks }}>\mathrm{L}_{\text {tabel }}$, maka Ho ditolak berarti data berdistribusi tidak normal

Adapun hasil perhitungan uji normalitas terhadap tes awal kelas eksperimen dan kelas kontrol dapat dilihat pada tabel 3 berikut:

Tabel 3. Hasil Uji Normalitas Skor Tes Awal

\begin{tabular}{ccccc}
\hline \multirow{2}{*}{ Kelas } & \multicolumn{3}{c}{ Normalitas } & \multirow{2}{*}{ Keputusan } \\
\cline { 2 - 4 } & $\mathbf{N}$ & $\mathbf{L}_{\text {maks }}$ & $\mathbf{L}_{\text {tabel }}$ & \\
\hline Eksperimen & 40 & 0,110 & 0,140 & Normal \\
Kontrol & 40 & 0,100 & 0,140 & Normal \\
\hline
\end{tabular}


Berdasarkan tabel 3 diketahui bahwa setelah dilakukan uji liliefors, skor $\mathrm{L}_{\text {maks }}$ menulis karangan narasi siswa kelas eksperimen dan kelas kontrol memenuhi kriteria $\mathrm{L}_{\text {maks }}<\mathrm{L}_{\text {tabel }}$ yaitu untuk kelas eksperimen $0,110<0,140$ dan kelas kontrol 0,100 < 0,140. Hal ini menunjukkan bahwa skor tes awal siswa kelas eksperimen dan kelas kontrol berdistribusi normal.

\section{b) Uji Homogenitas Skor Tes Awal Kelas Eksperimen dan Kelas Kontrol}

Berdasarkan uji normalitas, diketahui skor awal (pretest) kelas eksperimen dan kelas kontrol berdistribusi normal, maka selanjutnya dapat dilakukan uji homogenitas varians skor awal (pretest) kelas eksperimen dan kelas kontrol. Pengujian data ini dilakukan dengan teknik uji $\mathrm{F}$ (Fisher).

Perumusan hipotesis pengujian homogenitas varians tes awal (pretest) pada penelitian ini adalah sebagai berikut:
Ho : varians skor tes awal (pretest) kelas eksperimen dan kelas kontrol homogen (sama)

$\mathrm{Ha}$ : varians skor tes awal (pretest) kelas eksperimen dan kelas kontrol homogen (tidak sama)

Pengujian hipotesis menggunakan taraf signifikan $\alpha=0,05$ dan $F_{\text {tabel }}=1,70$ dengan kriteria sebagai berikut:

Jika $F_{\text {hitung }} \leq F_{\text {tabel }}$ maka Ho diterima, berarti varians kedua kelas homogen.

$F_{\text {hitung }}>F_{\text {tabel }}$ maka Ho ditolak, berarti varians kedua kelas tidak homogen.

Adapun hasil perhitungan homogenitas terhadap tes awal (pretest) dari kelas eksperimen dan kelas kontrol dapat dilihat pada tabel 4 berikut ini:

Tabel 4. Hasil Uji Homogenitas Skor Tes Awal

\begin{tabular}{ccccc}
\hline \multirow{2}{*}{ Kelas } & \multicolumn{3}{c}{ Homogenitas } & \multirow{2}{*}{ Keputusan } \\
\cline { 2 - 4 } & Varians & $\boldsymbol{F}_{\text {hitung }}$ & $\boldsymbol{F}_{\text {tabel }}$ & \\
\hline Eksperimen & 238,281 & 1,40 & 1.70 & \multirow{2}{*}{ Homogen } \\
Kontrol & 170,272 & 1,40 & & \\
\hline
\end{tabular}

Berdasarkan tabel 4 diatas dapat diketahui bahwa setelah dilakukan uji homogenitas skor tes awal (pretest) kelas eksperimen dan kelas kontrol maka didapatkan $F_{\text {hitung }}<F_{\text {tabel }}$ atau 1,40< 1,70. Hal ini berarti bahwa varians kelas eksperimen dan kelas kontrol bersifat homogen dan dilanjutkan dengan uji t.

\section{c) Uji Skor Tes Awal Kelas Eksperimen dan Kelas Kontrol}

Berdasarkan uji normalitas dan homogenitas terhadap skor tes awal (pretest) diperoleh bahwa kemampuan menulis karangan narasi siswa di kelas eksperimen dan kelas kontrol berdistribusi normal dan homogen. Selanjutnya dilakukan uji t untuk mengetahui ada atau tidaknya perbedaan signifikan antara skor rata-rata kelas eksperimen dan kelas kontrol, dengan hipotesis sebagai berikut:

Ho : Tidak terdapat perbedaan signifikan antara siswa kelas eksperimen dan siswa kelas kontrol

Ha : Terdapat perbedaan signifikan antara siswa kelas eksperimen dan siswa kelas control.

Pengujian hipotesis menggunakan taraf signifikan $\alpha=0,05$ dan $t_{\text {tabel }}=1,990$ dengan kriteria sebagai berikut:

$\mathrm{t}_{\text {hitung }} \leq \mathrm{t}_{\text {tabel }}$ maka Ho diterima dan Ha ditolak Adapun hasil dari uji t pada skor tes awal (pretest) dapat dilihat pada tabel 5 berikut: 
DOI : http://dx.doi.org/10.33578/jpfkip.v8i1.7556

ISSN : 2303-1514 | E-ISSN : 2598-5949

https://primary.ejournal.unri.ac.id/index.php/JPFKIP

Tabel 5. Hasil Uji t Tes Awal

\begin{tabular}{|c|c|c|c|c|c|c|}
\hline \multirow{2}{*}{ Kelas } & \multicolumn{5}{|c|}{ Uji t } & \multirow{2}{*}{ Keputusan } \\
\hline & $\overline{\mathbf{x}}$ & $\mathbf{S}$ & $S_{\text {gabungan }}$ & $t_{\text {hitung }}$ & $t_{\text {tabel }}$ & \\
\hline Eksperimen & 55,94 & 15,436 & & & & Tidak terdapat \\
\hline Kontrol & 56,25 & 13,049 & 14,3 & 0,097 & 1,990 & $\begin{array}{c}\text { perbedaan } \\
\text { yang } \\
\text { signifikan }\end{array}$ \\
\hline
\end{tabular}

Berdasarkan tabel 5 diketahui bahwa setelah dilakukan uji t, $t_{\text {hitung }}$ memenuhi kriteria $t_{\text {hitung }}<t_{\text {tabel }}$ atau $0,097<1,990$. Hal ini menunjukkan bahwa Ho diterima berarti tidak terdapat perbedaan yang signifikan antara kemampuan awal siswa kelas eksperimen dengan kelas kontrol pada tes awal (pretest).

\section{Analisis Skor Tes Akhir (Posttest)}

Tes akhir (Posttest) adalah tes yang diberikan kepada siswa setelah diberi perlakuan. Perlakuan pada kelas eksperimen adalah penggunaan media flash card, sedangkan perlakuan pada kelas kontrol adalah pembelajaran konvensional. Tujuan pemberian tes akhir (posttest) adalah untuk mengetahui pengaruh perlakuan yang diterapkan pada siswa. Hasil tes akhir (posttest) kedua kelas penelitian dapat dilihat pada tabel 6 berikut:

Tabel 6. Data Tes Akhir Kelas Eksperimen dan Kelas Kontrol

\begin{tabular}{ccccccc}
\hline Kelas & $\begin{array}{c}\text { Jumlah } \\
\text { siswa } \\
(\mathbf{n})\end{array}$ & $\begin{array}{c}\text { Rata- } \\
\text { Rata } \\
(\overline{\mathbf{x}})\end{array}$ & $\begin{array}{c}\text { Standar } \\
\text { Devisiasi } \\
(\mathbf{s})\end{array}$ & $\begin{array}{c}\text { Varians } \\
\left(\mathbf{s}^{2}\right)\end{array}$ & $\begin{array}{c}\text { Nilai } \\
\text { Minimal }\end{array}$ & $\begin{array}{c}\text { Nilai } \\
\text { Maksimal }\end{array}$ \\
\hline Eksperimen & 40 & 70,625 & 11,162 & 124,599 & 43,75 & 93,75 \\
Kontrol & 40 & 64,062 & 13,557 & 183,794 & 31,25 & 81,25 \\
\hline
\end{tabular}

Berdasarkan tabel 6 dapat dilihat bahwa terdapat perbedaan rata-rata skor tes akhir (posttest) antara kelas eksperimen dan kelas kontrol. Namun untuk mengetahui ada atau tidaknya perbedaan yang signifikan maka dilakukan uji perbandingan dua sampel yang saling bebas (uji t). Sebelum dilakukan uji t, maka terlebih dahulu dilakukan uji normalitas dan uji homogenitas terhadap skor tes akhir (posttest) kelas eksperimen maupun kelas kontrol.

\section{a) Uji Normalitas Skor Tes Akhir Kelas Eksperimen dan Kelas Kontrol}

Uji normalitas data ini dilakukan dengan menggunakan uji liliefors. Uji normalitas digunakan untuk mengetahui normalitas data skor tes akhir antara kelas eksperimen dan kelas kontrol, dengan perumusan hipotesis sebagai berikut:

Ho : skor tes akhir berdistribusi normal

$\mathrm{Ha} \quad$ : skor tes akhir berdistribusi tidak normal.

Pengujian hipotesis menggunakan taraf signifikan $\alpha=0,05$ dan $L_{\text {tabel }}=0,140$ dengan kriteria jika $\mathrm{L}_{\text {maks }} \leq \mathrm{L}_{\text {tabel }}$ maka Ho diterima berarti data berdistribusi normal.

Adapun hasil perhitungan uji normalitas terhadap tes akhir (posttest) dari kelas eksperimen dan kelas kontrol dapat dilihat pada tabel 7 berikut: 


\section{PRIMARY : JURNAL PENDIDIKAN GURU SEKOLAH DASAR \\ Volume 8 Nomor 2 Oktober 2019 \\ DOI : http://dx.doi.org/10.33578/jpfkip.v8i1.7556 \\ ISSN : 2303-1514 | E-ISSN : 2598-5949 \\ https://primary.ejournal.unri.ac.id/index.php/JPFKIP}

Tabel 7. Hasil Uji Normalitas Skor Tes Akhir

\begin{tabular}{ccccc}
\hline \multirow{2}{*}{ Kelas } & \multicolumn{3}{c}{ Normalitas } & \multirow{2}{*}{ Keputusan } \\
\cline { 2 - 4 } & $\mathbf{N}$ & $\mathbf{L}_{\text {maks }}$ & $\mathbf{L}_{\text {tabel }}$ & \\
\hline Eksperimen & 40 & 0,117 & 0,140 & Normal \\
Kontrol & 40 & 0,135 & 0,140 & Normal \\
\hline
\end{tabular}

Berdasarkan tabel 7 dapat diketahui bahwa skor tes akhir (posttest) siswa kelas eksperimen berdistribusi normal dan kelas kontrol berdistribusi normal dengan $\mathrm{L}_{\text {maks }}<\mathrm{L}_{\text {tabel }}$ yaitu $0,117<$ 0,140 untuk kelas eksperimen dan $0,135<0,140$ untuk kelas kontrol, kemudian dilanjutkan dengan uji homogenitas.

\section{b) Uji Homogenitas Skor Tes Akhir Kelas Eksperimen dan Kelas Kontrol}

Berdasarkan uji normalitas, diketahui skor akhir (posttest) kelas eksperimen dan kelas kontrol berdistribusi normal, maka selanjutnya dapat dilakukan uji homogenitas varians skor tes akhir (posttest) kelas eksperimen dan kelas kontrol. Pengujian homogenitas data ini dilakukan dengan teknik uji $\mathrm{F}$ (Fisher).
Perumusan hipotesis pengujian homogenitas varians tes akhir (posttest) pada penelitian ini adalah sebagai berikut:

Ho : Varians skor tes akhir (posttest) kelas eksperimen dan kelas kontrol homogen (sama)

Ha : Varians skor tes akhir (posttest) kelas eksperimen dan kelas kontrol tidak homogen (tidak sama)

Pengujian hipotesis menggunakan taraf signifikan $\alpha=0,05$ dan $F_{\text {tabel }}=1,70$ dengan kriteria, jika $F_{\text {hitung }} \geq F_{\text {tabel }}$ maka $\mathrm{H}_{\mathrm{o}}$ diterima berarti varians kedua kelas tidak homogen.

Adapun hasil perhitungan homogenitas terhadap tes akhir (posttest) dari kelas eksperimen dan kelas kontrol dapat dilihat pada tabel 8 berikut:

Tabel 8. Hasil Uji Homogenitas Skor Tes Akhir

\begin{tabular}{ccccc}
\hline \multirow{2}{*}{ Kelas } & \multicolumn{3}{c}{ Homogenitas } & \multirow{2}{*}{ Keputusan } \\
\cline { 2 - 4 } $\begin{array}{c}\text { Varians } \\
\text { Eksperimen }\end{array}$ & $\begin{array}{c}\mathbf{F}_{\text {hitung }} \\
\text { Kontrol }\end{array}$ & 124,599 & $\mathbf{F}_{\text {tabel }}$ & \\
\hline
\end{tabular}

Berdasarkan tabel 8 dapat diketahui bahwa setelah dilakukan uji homogenitas skor tes akhir (posttest) siswa kelas eksperimen dan kelas kontrol dengan taraf signifikan $\alpha=0,05$, maka didapatkan $\mathrm{F}_{\text {hitung }}<\mathrm{F}_{\text {tabel }}$ atau $1,48<1,70$. Hal ini menunjukkan berarti bahwa varians kelas eksperimen dan kelas kontrol bersifat homogen dan dapat dilanjutkan dengan uji t.

\section{c) Uji t Skor Tes Akhir Kelas Eksperimen dan Kelas Kontrol}

Berdasarkan uji normalitas dan homogenitas terhadap skor tes akhir (posttest) diperoleh bahwa kemampuann menulis karangan narasi siswa di kelas eksperimen dan kelas kontrol berdistribusi normal dan tidak homogen. Setelah itu, pengujian skor dilanjutkan dengan menggunakan uji $\mathrm{t}$ untuk mengetahui ada atau tidaknya perbedaan signifikan antara skor rata-rata kelas eksperimen dan kelas kontrol, dengan hipotesis sebagai berikut:

Ho : Tidak terdapat perbedaan signifikan antara siswa kelas eksperimen dan siswa kelas control

Ha : Terdapat perbedaan signifikan antara siswa kelas eksperimen dan siswa kelas kontrol

Pengujian hipotesis menggunakan taraf signifikan $\alpha=0,05$ dan $t_{\text {tabel }}=1,990$ dengan kriteria sebagai berikut:

$t_{\text {hitung }} \leq \mathrm{t}_{\text {tabel }}$ maka Ho diterima dan Ha ditolak.

Adapun hasil dari uji t pada skor tes akhir

(posttest) dapat dilihat pada tabel 9 berikut: 


\section{PRIMARY : JURNAL PENDIDIKAN GURU SEKOLAH DASAR \\ Volume 8 Nomor 2 Oktober 2019 \\ DOI : http://dx.doi.org/10.33578/jpfkip.v8i1.7556 \\ ISSN : 2303-1514 | E-ISSN : 2598-5949 \\ https://primary.ejournal.unri.ac.id/index.php/JPFKIP}

Tabel 9. Hasil Uji t Tes Akhir

\begin{tabular}{ccccccc}
\hline \multirow{2}{*}{ Kelas } & \multicolumn{5}{c}{ Uji t } & \multirow{2}{*}{ Keputusan } \\
\cline { 2 - 5 } Eksperimen & $\overline{\mathbf{x}}$ & $\mathbf{S}$ & $\boldsymbol{S}_{\text {gabungan }}$ & $\mathbf{t}_{\text {hitung }}$ & $\mathbf{t}_{\text {tabel }}$ & Terdapat \\
& 70,625 & 11,162 & 12,42 & 2,363 & 1,990 & $\begin{array}{c}\text { perbedaan } \\
\text { yang } \\
\text { signifikan }\end{array}$ \\
\hline
\end{tabular}

Berdasarkan tabel 9 diketahui bahwa setelah dilakukan uji $\mathrm{t}, \mathrm{t}_{\text {hitung }}$ memenuhi kriteria dan $t_{\text {hitung }}>t_{\text {tabel }}$ atau 2,363 >1,990. Hal ini menunjukkan Ho ditolak dan Ha diterima berarti terdapat perbedaan yang signifikan antara siswa kelas eksperimen dengan siswa kelas kontrol pada tes akhir. Dengan kata lain, terdapatnya perbedaan nilai rata-rata yang signifikan antara kelas eksperimen dan kelas kontrol.

\section{Effect Size (ES)}

Digunakan untuk mengetahui seberapa besar pengaruh penggunaan media flash card terhadap kemampuan menulis karangan narasi siswa. Dengan kriteria, jika:

$\mathrm{ES}<0,3=$ Digolongkan rendah

$0,3<\mathrm{ES}<0,7=$ Digolongkan sedang

$\mathrm{ES}>0,7 \quad=$ Digolongkan tinggi

Tabel 10. Analisis Effect Size nilai posttest kelas eksperimen dan kelas kontrol

\begin{tabular}{ccccc}
\hline & \multicolumn{4}{c}{ Effect Size } \\
\hline Kelas & $\overline{\mathbf{x}}$ & $\mathbf{S}$ & Hasil & Keputusan \\
\hline Eksperimen & 70,625 & - & \multirow{2}{*}{0,5} & Sedang \\
\hline Kontrol & 64,0625 & 13,56 & & \\
\hline
\end{tabular}

Berdasarkan tabel 10 diketahui bahwa setelah dilakukan uji Effect Size, didapatlah ES sebesar 0,5. Dengan demikian ES memenuhi kriteria dengan $0,3<\mathrm{ES}<0,7$ atau $0,3<0,5<$ 0,7 . Hal ini menunjukkan bahwa pengaruh media flash card terhadap keterampilan menulis karangan narasi siswa termasuk dalam kategori sedang.

Rincian nilai siswa pada keterampilan menulis sebelum menggunakan media flash card dalam pembelajaran adalah kelas A (kelas kontrol) pada saat pretest terdapat 2 siswa yang terampil, 24 siswa cukup terampil, 14 siswa kurang terampil. Pada kelas B (kelas eksperimen) terdapat 2 siswa dalam kategori terampil, 20 siswa cukup terampil, 18 siswa kurang terampil. Rincian nilai siswa pada keterampilan menulis sesudah menggunakan media flash card dalam pembelajaran adalah kelas $\mathrm{A}$ (kelas kontrol) pada saat posttes terdapat 3 siswa yang terampil, 30 siswa cukup terampil, 7 siswa kurang terampil. Pada kelas B (kelas eksperimen) terdapat 5 siswa kategori sangat terampil, 5 siswa terampil, 28 siswa cukup terampil, dan 2 siswa kurang terampil.

\section{Pembahasan}

Penelitian ini dilaksanakan di kelas III SD Negeri 188 Pekanbaru. Berdasarkan penelitian yang sudah dilakukan peneliti memperoleh fakta yaitu penggunaan media flash card dapat dikatakan berpengaruh terhadap keterampilan menulis karangan narasi. Sadiman (2009) mengatakan bahwa media adalah segala sesuatu yang dapat dipergunakan untuk menyalurkan pesan dari pengirim ke penerima

pesan sehingga dapat merangsang pikiran, perasaan, perhatian dan minat siswa sedemikian rupa sehingga proses belajar terjadi. Seperti yang ditunjukkan pada siswa yang diberi perlakuan menggunakan media flash card mendapatkan nilai rata-rata lebih tinggi dibanding dengan 
pembelajaran pada siswa yang tidak diberi perlakuan, karena imajinasi siswa dalam menulis lebih tinggi apabila siswa tersebut diberi rangsangan berupa flash card.

Berdasarkan analisis data didapatkan beberapa temuan beserta pembahasannya yaitu adanya pengaruh penggunaan media flash card terhadap keterampilan menulis karangan narasi yang diterapkan. Pembahasan terhadap hasil penelitian dibuat berdasarkan analisis dan temuantemuan dilapangan dengan disertai data-data yaitu: tes awal (pretest), dan tes akhir (posttest). Berdasarkan uji perbedaan rata-rata skor tes awal (pretest) yang dilakukan tidak memiliki perbedaan yang signifikan. Hal ini didasarkan pada uji t kelas eksperimen dan kelas kontrol yang memiliki $t_{\text {hitung }} 0,097$ dan $t_{\text {tabel }} 1,990$ sehingga keterampilan awal siswa kelas eksperimen dan kelas kontrol memenuhi kriteria $t_{\text {hitung }}<t_{\text {tabel }}$ atau $0,097<1,990$. Hal ini menunjukkan bahwa $H_{O}$ diterima, berarti tidak terdapat perbedaan yang signifikan antara kelas eksperimen dan kelas kontrol pada tes awal (pretest). Dengan demikian, dari uji perbedaan tersebut siswa kelas eksperimen dengan siswa kelas kontrol memiliki kemampuan dan keterampilan yang sama atau tidak terdapat perbedaan yang signifikan pada kemampuan menulis karangan narasi sebelum diterapkan atau diberi perlakuan.

Hasil analisis terhadap skor akhir (posttest), diketahui bahwa siswa yang belajar menggunakan media pembelajaran di kelas eksperimen memiliki peningkatan rata-rata dari 55,9 menjadi 70,6 dengan standar deviasi 15,4 sedangkan kelas kontrol memiliki rata-rata 56,3 menjadi 64,1 dengan standar deviasi 13,6. Berdasarkan perbedaan rata-rata tes akhir (posttest) tersebut dapat dilihat bahwa terdapat pengaruh penggunaan media flash card terhadap keterampilan menulis karangan narasi dikelas eksperimen dan pembelajaran konvensional dikelas kontrol. Perbedaan ini didasarkan pada hasil uji t diperoleh $\mathrm{t}_{\text {hitung }}$ memenuhi kriteria $\mathrm{t}_{\text {hitung }}>$ $t_{\text {tabel }}$ atau 2,363 > 1,990. Hal ini menunjukkan $\mathrm{H}_{\mathrm{o}}$ ditolak dan $\mathrm{Ha}$ diterima berarti terdapat pengaruh yang signifikan antara siswa kelas eksperimen dan siswa kelas kontrol pada kemampuan akhir. Selaras dengan hasil penelitian tersebut, Arsyad
(2016) mengatakan bahwa penggunaan media flash card dalam pembelajaran merupakan suatu proses, cara menggunakan kartu belajar yang efektif berisi gambar, teks, atau tanda simbol untuk membantu mengingatkan atau mengarahkan siswa kepada sesuatu yang berhubungan dengan gambar, teks, atau tanda simbol yang ada pada kartu, serta merangsang pikiran dan minat siswa dalam meningkatkan kecakapan pengenalan simbol bahan tulis dan kegiatan menurunkan simbol tersebut sampai kepada kegiatan siswa memahami arti/ makna yang terkandung dalam bahan tulis.

Untuk mengetahui seberapa besar berpengaruhnya media flash card terhadap keterampilan menulis karangan narasi siswa maka diukur dengan menggunakan Effect Size, didapatlah ES sebesar 0,5. Ini berarti memenuhi kriteria 0,3 $<$ ES $<0,7$ atau 0,3 $<0,5<0,7$ yang berarti bahwa pengaruh media flash card terhadap keterampilan menulis karangan narasi siswa termasuk dalam kategori sedang.

Fakta ini diperkuat dengan penelitian yang dilakukan oleh Angraeny dan Syukur Saud dengan judul "Keefektifan Media Pembelajaran Flash Card Dalam Keterampilan Menulis Karangan Sederhana Bahasa Jerman Siswa Kelas XI IPA SMA Negeri 9 Makasaar" menyatakan bahwa media pembelajaran ini merupakan suatu alternatif dalam keterampilan menulis karangan bahasa Jerman, karena membuat siswa menjadi aktif dan kreatif dalam membuat sebuah karangan berdasarkan flash card atau kartu bergambar yang didapatkan oleh siswa. Hal tersebut dibuktikan dengan hasil analisis data yang telah dilakukan dengan nilai posttet siswa setelah dilakukan uji t pada masing-masing kelompok dengan $t_{\text {hitung }}$ $=6,17>t_{\text {tabel }}=1,998$ pada taraf signifikan 0,05 yang berarti bahwa pembelajaran flash card efektif dalam keterampilan menulis karangan sederhana bahasa Jerman siswa kelas XI IPA SMA Negeri 09 Makasaar.

Penelitian yang mendukung juga pernah dilakukan oleh Milla Nahdliya Ulwiya (2018) dalam penelitiannya yang berjudul "Penggunaan Media Flash Card Untuk Meningkatkan keterampilan Menulis Deskripsi Siswa Sekolah Dasar" menyatakan bahwa penggunaan media flash card untuk meningkatkan keterampilan menulis deskripsi siswa kelas IV SDN Gembongan 
2 Blitar dapat dikatakan berhasil. Dapat dilihat dari rata-rata nilai siswa mengalami peningkatan sebesar 1,89, sedangkan ketuntasan belajar siswa secara klasikal pada siklus I 62,5\% dan siklus II mencapai $87,5 \%$.

Sejalan dengan penelitian di atas, Aulia Ratna Sari pernah melakukan penelitian dengan judul "Keefektifan Media Pembelajaran Flash Card Dalam Pembelajaran Menulis Prosedur Kompleks Siswa Kelas X SMA Negeri 6 Yogyakarta" menyatakan bahwa (1) ada perbedaan kemampuan menulis prosedur kompleks yang signifikan antara siswa yang mendapatkan pembelajaran menulis prosedur kompleks dengan menggunakan media flash card dan siswa yang konvensional, (2) media flash card efektif digunakan dalam pembelajaran menulis prosedur kompleks siswa kelas X SMA N egeri 6 Yogyakarta. Diketahui dari selisih kenaikan skor rata-rata hitung antara kedua kelompok sebesar 3,09.

Peneliti lain yang melakukan penelitian serupa adalah Eva Wulansari (2014) dengan judul "Keefektifan Penggunaan Media Flash Card Dalam Pembelajaran Keterampilan Menulis Bahasa Jerman Di SMA Negeri 1 Sedayu Bantul". Dari penelitiannya di dapat hasil bahwa penggunaan media flash card dalam pembelajaran keterampilan menulis bahasa jerman lebih efektif dari pada menggunakan media konvensional. Hasil penelitian menunjukkan bahwa $t_{\text {hitung }}$ sebesar 2,009 dengan db 48 dengan taraf signifikan 5\%.

Penelitian yang dilakukan oleh Anggraini D.R., dkk (2019) dengan judul "Keefektifan Model Picture and Picture Berbantu Media Flashcard Terhadap Keterampilan Menulis Karangan". Didapat bahwa hasil belajar siswa yang mendapat pembelajaran menggunakan model pembelajaran Picture and Picture berbantu media

\section{SIMPULAN DAN REKOMENDASI}

Berdasarkan analisis dan pembahasan yang telah diuraikan mengenai pengaruh penggunaan media flash card terhadap keterampilan menulis karangan narasi siswa kelas III SD Negeri 188 Pekanbaru, maka dapat disimpulkan bahwa: 1) Hasil posttest diperoleh bahwa rata-rata keterampilan siswa dalam menulis karangan narasi dengan menggunakan media flash card (kelas
Flashcard lebih baik dari pada menggunakan model konvensional.

Penelitian yang dilakukan oleh Lilis Trisnanti, dkk (2018) dengan judul "Pengaruh Media Flash card Bilingual Terhadap Kemampuan Kosakata Bahasa Inggris Permulaan Anak Kelompok B TK Gugus Mawa”. Dapat disimpulkan bahwa terdapat pengaruh media flashcard bilingual terhadap kemampuan kosakata bahasa Inggris permulaan pada anak kelompok B di TK Gugus Mawa Kecamatan Denpasar Selatan Tahun Pelajaran 2017/2018.

Penelitian dari Helda Lisa 2019 dengan judul "The Effectiveness of Flash Card on The Motivation to Increase English Vocabular Among The Fourth Elementary School". Hasil analisis menunjukkan bahwa ada perbedaan yang signifikan antara motivasi belajar kosakata bahasa Inggris di antara siswa kelas empat sekolah dasar sebelum penerapan kartu flash dan setelah implementasi $(76,6 \%)$, dan ada perbedaan yang signifikan antara penguasaan kosakata bahasa Inggris siswa sekolah dasar kelas empat yang diajarkan dengan menggunakan kartu flash dan orang-orang yang diajarkan tanpa menggunakan kartu flash $(\mathrm{t}=7,74)$.

Allen (dalam Nanci A. Scheetz 2012 Deaf Education in the 21ST Century. Pearson Education, Inc.) menyatakan bahwa dari hasil penelitian Allen mengungkapkan bahwa kesulitan yang dialami baik anak kurang mampu dengar maupun tuli total ketika disajikan dengan materi yang tertulis, sehingga anak kurang mampu dalam menangkap informasi yang tertulis. Dengan demikian, penelitian ini menunjukkan bahwa penggunanaan media flash card mampu membantu proses pembelajaran keterampilan menulis dari pada menggunakan media konvensional.

eksperimen) lebih tinggi dibandingkan rata-rata keterampilan menulis yang tidak menggunakan media (kelas kontrol). Rata-tata nilai pretest yang diperoleh kelas eksperimen yaitu 55,94 sedangkan rata-rata kelas kontrol yaitu 56,25. Setelah dilakukan tindakan pada dua kelas, maka diperoleh rata-rata nilai posttest kelas eksperimen yaitu sebesar 70,63 dan kelas kontrol sebesar 64,06. 
Perhitungan hipotesis dengan menggunakan uji-t diperoleh memenuhi kriteria $t_{\text {hitung }}>$ $t_{\text {tabel }}$ atau 2,363 $>1,990$. Hal ini menunjukkan Ho ditolak dan $\mathrm{Ha}$ diterima berarti terdapat perbedaan yang signifikan antara kelas eksperimen dan kelas kontrol pada tes akhir. Hal ini menunjukkan penggunaan media flash card berpengaruh terhadap keterampilan menulis karangan narasi siswa; 2) Hasil uji Effect Size didapat $E S$ sebesar 0,5. Dengan demikian ES memenuhi kriteria dengan $0,3<E S<0,7$. Hal ini menunjukkan bahwa penggunaan media flash card berpengaruh (kategori sedang) dalam keterampilan menulis karangan narasi siswa kelas III SDN 188

\section{DAFTAR PUSTAKA}

Amaliyah, S. (2018). Penggunaan Media Gambar Untuk Meningkatkan Keterampilan Menulis Paragraf Deskripsi Siswa Kelas IV SD Muhammadiyah 6 Pekanbaru. Skripsi tidak dipublikasikan. Pekanbaru: FKIP Universitas Riau.

Anggraini, D. R., dkk. (2019). Keefektifan Model Picture And Picture Berbantu Media Flashcard Terhadap Keterampilan Menulis Karangan. International Journal Elementary of Education 3 (1), 2579-7158

Angreany, F., \& Saud, S. (2017). Keefektifan Media Pembelajaran Flashcard dalam Keterampilan Menulis Karangan Sederhana Bahasa Jerman Siswa Kelas XI IPA SMA Negeri 9 Makassa. Eralingua Jurnal Pendidikan Bahasa Asing dan Sastra, 1 (2), 138-146.

Aningsih, \& Asih (2017). Pengaruh Penggunaan Media Flash Card Terhadap Keterampilan Menulis Karangan Narasi Siswa Kelas V Karang Satria 05 Tambun Utara Bekasi. Pedagogik V(1), 1-9.

Arsyad, A. 2009. Media Pembelajaran. Jakarta: PT Raja Grafindo Persada.

Fitriyani, E., et.al. (2017). Efektivitas Media Flash Cards dalam Meningkatkan Kosakata Bahasa Inggris. Psympathic, Jurnal Ilmiah Psikologi, 4 (2), 167-182

Khasanah, N. (2011). Peningkatan Keterampilan Menulis Rangkuman Buku melalui Ide Pokok dengan Media Flash Card pada
Pekanbaru.

Peneliti akan merekomendasikan beberapa saran yang penggunaannya dalam proses belajar mengajar khususnya dalam menulis karangan narasi melalui media flash card sebagai berikut: 1) Guru diharapkan mengembangkan kreatifitas dalam proses pembelajaran dan menggunakan media sebagai rangsangan untuk memberikan dorongan siswa dalam meningkatkan keterampilan menulis karangan narasi; 2) Bagi peneliti berikutnya sebagai referensi dalam menyelesaikan penelitian yang serupa dengan menggunakan media flash card.

siswa Kelas VIII C SMP Negeri 1 Gemuh Kabupaten Kendal Tahun Ajaran 2010/2011. Skripsi. Fakultas Bahasa dan Seni Universitas Negeri Semarang.

Khoriyah, S. A. (2013). Pemanfaatan Media Flash Card Untuk Meningkatkan Penguasaan Mufradat Siswa Kelas VII A MTs N NGemplak Sleman Yogyakarta Tahun Ajaran 2012/2013". Skripsi Universitas Islam Sunan Kalijga Yogyakarta.

Lisa, H. (2019). The Effectiveness Of Flash Card On The Motivation To Increase English Vocabular Among The Fourth Elementary School. JOALL (Journal of Applied Linguistics and Literature), 4(1), 2503-524 DOI: 10.33369/joall.v4i1.6852.

Made, et.all. (2015). Pengaruh Penggunaan Media Flash Card Terhadap Minat dan Hasil Belajar IPA Peserta Didik Kelas VI SDLBB Negeri Tabanan. E-journal Program Pasca Sarjana. Program Studi Penelitian dan Evaluasi Pendidikan, 5 (1).

Nanci, S. (2012). Deaf Education In The 21ST Century: Pearson Education, Inc.

Nurgiyantoro. (2014). Penilaian Pembelajaran Bahasa Indonesia Berbasis Kompetensi. Yogyakarta: BPFE-YOGYAKARTA.

Purwanto, N. 2010. Prinsip-prinsip dan Teknik Evaluasi Pengajaran. Bandung: Remaja Rosda Karya.

Putri, R. P. (2017). Pengaruh Penggunaan Media Gambar seri Terhadap Keterampilan 
Menulis Karangan Narasi siswa Kelas IV SDN 37 Pekanbaru. Skripsi tidak dipublikasikan. FKIP Universitas Riau. Pekanbaru.

Sari, A. R. (2015). Keefektifan Media Flash Card Dalam Pembelajaran Menulis Prosedur Kompleks Siswa Kelas $X$ SMA 6 Yogyakarta. Skripsi. Fakultas Bahasa dan Seni. Universitas Negeri Yogyakarta.

Sutrisno, L., dkk. (2008). Pengembangan Pembelajaran IPA SD. Direktorat Jenderal Pendidikan Tinggi Departemen Pendidikan Nasional.

Trisnanti, L .,ett.all. (2018). Pengaruh Media Flashcard Bilingual Terhadap Kemampuan Kosakata Bahasa Inggris Permulaan Anak Kelompok B TK Gugus Mawa Kecamatan Denpasar Selatan Tahun Pelajaran 2017/2018. e-Journal Pendidikan Anak Usia Dini Universitas Pendidikan Ganesha $6(1)$.

Ulwiya, M. N. (2018). Penggunaan Media Flash card Untuk Meningkatkan Keterampilan Menulis Deskripsi Siswa di Sekolah Dasar. JPGSD, 06 (04), 536-545.

Wulansari, E. (2014). Keefektifan Penggunaan Media Flash Card dalam Pembelajaran Keterampilan Menulis Bahasa Jerman di SMA Negeri 1 Sedayu Bantul. Skripsi. Fakultas Bahasa dan Seni Universitas Negeri Yogyakarta.

Yulianti, T. (2017). Penerapan Model Pembelajaran Think Talk Write (TTW) Untuk Meningkatkan Keterampilan Menulis Karangan Narasi Siswa Kelas III A SDN 188 Pekanbaru. Skripsi tidak dipublikasikan. FKIP Universitas Riau. Pekanbaru. 